\title{
Crossing Borders: Academe and Cultural Agency in Agricultural Research
}

\author{
Robert W. Blake ${ }^{1,2}$, Elvira E. Sanchez-Blake ${ }^{3}$ \& Debra A. Castillo ${ }^{4}$ \\ ${ }^{1}$ Department of Animal Science and director of the Center for Latin American and Caribbean Studies \\ (2009-2014), Michigan State University, East Lansing, Michigan, USA \\ ${ }^{2}$ Professor Emeritus, Department of Animal Science, Cornell University, Ithaca, New York, USA \\ ${ }^{3}$ Department of Romance and Classical Studies, Michigan State University, East Lansing, Michigan, USA \\ ${ }^{4}$ Department of Comparative Literature, Stephen H. Weiss Presidential Fellow, and Emerson Hinchcliff \\ Professor of Hispanic Studies, Cornell University, Ithaca, New York, USA \\ Correspondence: Robert W. Blake, Department of Animal Science, Michigan State University, East Lansing, \\ Michigan 48824, USA. E-mail: rwblake@msu.edu
}

Received: November 9, 2014 Accepted: December 8, 2014 Online Published: January 15, 2015

doi:10.5539/jas.v7n2p9 URL: http://dx.doi.org/10.5539/jas.v7n2p9

\begin{abstract}
This article explores social educator actions by academe as cultural agency's natural partner in ways that echo, connect and create plural discourse among the many dimensions and disciplines of society. Based on collaborations with Mexican partners, we argue this goal is achieved with multiplicative effects when students and faculty, key agents themselves and trainers of intercultural agents, learn first-hand by crossing borders to frame issues and work together to articulate collaborative research problems. In so doing a more inclusive worldview becomes integral context in needs assessments. This has been our long-standing pedagogical approach in leading students-undergraduates and graduates-and faculty from around the world on a multidisciplinary, intergenerational examination of rural and urban development in tropical Latin America. Greater academic agency through more alliances of this kind is needed to better achieve equity goals supported by greater investments targeting community engagement and applied problem-solving. We illustrate this learning framework and provide specific livestock research cases in southern Mexico that reveal potentials realized by bringing academe to the field and the field to academe, as part of a reinforcing educational process that promotes understanding and social transformation.
\end{abstract}

Keywords: academic alliances, agriculture, community engagement, cultural agency, southern Mexico, trading places

\section{Crossing Borders}

Ours is a story of encounters and problems needing solution. Different worlds reach out to one another on a transformative life stage obtained by crossing borders. For more than four decades Cornell University has led annual groups of 25 to 35 participants totaling about 2000 students-undergraduates and graduates - and faculty from around the world on a two-course multidisciplinary, intergenerational examination of rural and urban development in tropical Latin America. The field component of these courses has been conducted in Puerto Rico, Dominican Republic, Costa Rica, Honduras, Ecuador and Mexico. With library and lecture traded in the second course for mountaintops and mangrove swamps, aspiring intercultural scholars learn first-hand from real-world knowledge providers, some who are highly marginalized.

This year-long experience, which is training ground also for participating faculty, includes a preparatory course (Note 1), followed by an intense research experience (Note 2) that includes at least two weeks in the field and a subsequent on-campus agenda of distillation, analysis, and reporting. Preparation for informed and respectful dialogue in the field by our constituency, including students and faculty from collaborating institutions through videoconferencing, starts with the on-campus course in the preceding semester. This initial course is designed to introduce participants to basic cultural, historical, socio-political, literary, anthropological, linguistic, health, agricultural and food system, and social and family welfare issues that they are likely to observe first-hand. Inequality, possibly the key global social issue of our time, especially in the Americas, constitutes a dominant 
underlying theme. Besides a gap in earned income, social inequality stems also from unequal access to food, land, education at all levels, health services, markets, credit, capital and justice.

A complementary Spanish section for students with basic language skill was devoted to further discussion of topics from lectures and supported by additional readings in Spanish. In the field, recognizing the authority of "other" voices is crucial. Especially valuable are personal interactions "in culturally authentic and acceptable ways" (Meredith, 2010). Some of our hosts are indigenous peoples whose mother tongue is not Spanish, themselves learners of a second language and culture. We see this step towards intercultural practice, made more democratic by plural discourse, as obligatory in a world perceived by some to be increasingly dominated by a "globalization that flattens everything in its path" (Godenzzi, 2006). This platform, where academe learns from cultural agents-those whose actions affect collective change (Note 3)-evolved into a shared, live, video-streamed seminar during 2008-11 involving our universities as well as Mexican collaborators. Sandwiched between the two campus-based courses was the field experience itself, where we strengthened our ties to individuals and host institutions, including El Colegio de la Frontera Sur, el Centro de Investigaciones y Estudios Superiores en Antropología Social, and the Instituto Nacional de Investigaciones Forestales, Agrícolas y Pecuarias (INIFAP) (Note 4).

This article demonstrates how encounters during our field explorations helped students and faculty members alike to articulate problems, establish contacts, and develop subsequent research investigations based on these contextualized settings and inputs by our hosts. We illustrate how this consolidated pedagogical and problem-framing approach contributes to the intellectual growth of students and faculty alike with a sample of agricultural research outcomes built upon issues initiated by boots-on-the-ground field experiences. William B. Lacy (Note 5) summarized the achievement of this living laboratory undertaking (Note 6):

Experience Latin America is one of the richest learning experiences I have seen in higher education. The dynamic international learning environment is greatly enhanced by bringing together undergraduates and graduates with diverse backgrounds and international experiences with a multidisciplinary, intergenerational group of faculty, administrators, and extension educators. Each of the participants becomes an active learner and teacher... (Blake, 2001).

Correspondingly, our learning forum is designed to share and to build knowledge, responding to what Godenzzi calls the great challenge of the twenty-first century, "the construction of an ethic of respect and solidarity" (2006). It strives to demonstrate tolerance, inclusion and value enhancement through a celebration of cultural difference. Students and faculty typically represent Africa, Asia and Europe as well as half a dozen countries from the Americas (including other regions in the host country). Accordingly, the program objectives are to explore equity-gap challenges, acknowledging rural-urban disparities and aspects of cultural heritage, improving intercultural dialogue, and fostering greater contact and communication among the players, e.g., in-country hosts, students from afar as well as the host country, faculty and other professionals.

Clearly it is not possible in a mere two weeks to thoroughly examine the many facets of the many problems faced by families in many settings. Nevertheless, the field laboratory provides a valuable opportunity to see first-hand how they live, to see their crops and animals, to speak with and learn from them, to visit projects of various institutions designed to serve them, and to listen to professionals who have devoted careers to these challenges. As Professor H. David Thurston, a leader in this enterprise summarized (Thurston, 2001), "I feel the essence of the field trip... is that the students... have had the chance to 'touch it, feel it and smell it.' The course brings a vast array of experiences into focus in settings that cannot be equaled in a classroom." Correspondingly, we follow a beacon similar to the one provided to painter Georgia O'Keefe by her mentor, Professor Arthur W. Dow (Note 7)-structure one's work in better comprehending nature, landscapes, people and their livelihood systems "by not (only) mastering particular facts, but by seeing, experiencing, and creating (your) own systems or structures."

\subsection{Course Organization}

A hallmark among Cornell's study abroad options, "Agriculture in Developing Nations" evolved with our understanding of agriculture and development from primarily graduate students in the agricultural sciences in the early years, to a gender, disciplinary and culturally-equitable mix of both undergraduate and graduate students from across the university and the globe, now branded Experience Latin America. Enrichments to this learning forum included participation also by extension educators, field activities designed to better grasp the major issues, and thematic teams to assess complex issues based on observation, consultation with hosts, and relevant literature.

Students are challenged to reconcile multiple facets with potentially competing goals in order to grasp 
pragmatically, and in ways witnessed to have touched our hosts, the complex issues of rural development. Jason Ingram summed up the experience of many others (Blake, 2001),

"I cannot stress the impact that this class had on me. It was one of the rare times when I felt that, having seen a well-rounded example of an issue, I could form an opinion based on my own observations, not just on what I had been shown in a classroom."

The relationships among the sometimes competing goals of poverty alleviation, economic growth and the sustainable use of the environment and its natural resources help define a basic learning framework. Participants grapple for balance among them-and corresponding impacts on human welfare-within the context of the host nation's complex food, environmental, economic and social systems. Culturally and experientially diverse participants also learn to debate more effectively and to better negotiate disparate or conflicting viewpoints into collaboration, aided by hands-on opportunities and guidance in choosing effective criteria to better figure things out for themselves.

From the outset of the field component, participants are organized into multidisciplinary theme groups with faculty facilitators. Each group comprises undergraduate and graduate students in several disciplines, international and US students, and Spanish-language competency. In addition to class discussions to daily process our observations, theme groups continue to deliberate throughout the field trip and subsequently in preparing written projects and their oral team presentations. Findings from rapid appraisals during the field study are also reported using this mechanism. Rapid appraisal exercises include mapping farm resources, mapping community transects, constructing a multi-layer annual calendar of agricultural, household and community activities, and outlining a community and family history of agriculture and resource use. The expectation is that farm visits provide a powerful thread for connecting one's own experiential learning with the learning that comes from reading and discussions also involving our hosts, which may immediately help students to formulate their own projects, including potential return for thesis work.

Themes groups vary with the expertise held by the participating faculty as well as the interests of students. For example, themes in one Experience Latin America edition were: Rural Realities: Livelihood systems in Chiapas; Politics, Identity and Society; and Indigenous Cultural Expression and Performance. Another edition focused on complementary livelihoods-related issues: Livelihood Systems in Mexico's Gulf Region: Which are the priority information needs, policies and programs? and Livelihood Systems in Mexico's Gulf Region: How to make research and extension relevant? Associated considerations were the potential "action plans" to increase the impact of research and extension, better understanding how information needs, interests and knowledge systems of resource-limited farmers differ from those with greater endowments, and the roles of farmer organizations and alliances with universities and government and nongovernmental organizations.

\section{Research Aim: Agrarian Vulnerability}

These living laboratory experiences provided opportunities for our participants to gain awareness and to learn about some of the rural realities that encompass many issues separately addressed by the academy. Farm visits initiated learning and insight about real-world issues concerning food production, land and water, climate change, biodiversity, family and community welfare, and the economic challenges faced by agrarian society. Conversations with farmers, indigenous folks, and other hosts helped articulate needs and contemporary challenges. Recognizing that valuable intellectual work and analysis take place in all disciplines, cultural agency and performance studies were also integrated into our portfolio of pedagogical interactions and the process of articulating researchable problems. Consequently, graduate and undergraduate student researchers developed projects and publications with the dual purposes of pursuing real-world issues and giving something back to our hosts and others with similar needs and interests.

We now illustrate our approach by describing an encounter with the Génesis farmers' organization, which subsequently led to the multi-institutional research collaboration by Absalon et al. (2012a, 2012b). Our group had been invited to the Génesis annual meeting and barbacoa (barbecue) at Rancho El Yualito, on the central coastal plain near Cotaxtla, Veracruz. Dozens of these cooperative members, owners of farms with dual-purpose cattle systems to produce milk and beef gathered with their families for business meetings, reporting and festivities. Reports included on-farm technology testing (and viewing of livestock), hearing from INIFAP advisors on technical and financial matters, and reviewing collaborative work plans for the coming year.

The Génesis encounter was graciously arranged and co-hosted by Dr. Francisco Juárez Lagunes, a Cornell alumnus and research scientist for INIFAP and professor at Universidad Veracruzana, along with Génesis farmers. Our El Yualito arrival was like finding a bustling, sunny-day county fair-a parking area for vehicles; streams of people, and unloading cattle from trucks; multi-colored banners; lively music booming from 
loudspeakers; Génesis men all in red shirts like twins requete multiplied (galore); smiling wives, mothers and daughters assuring order over chaos, organizing tables, chairs, projectors and screens; cauldrons of carnitas (savory pork) on open fires; and easels displaying posters reporting on-farm research with figures and photographs. Clearly, this was a celebration of successful cooperative action. Upon arrival our international delegation was warmly received by José Ausencio Muñíz Morales, owner of El Yualito, and his nephew, José Miguel Ruíz Espinoza. José Miguel, a former high school exchange student in the US, was urged to address our group on equal ground as Génesis' bi-lingual spokesperson. Greetings and introductory remarks led to a farm tour, presentations, questions and many individual conversations, and ample opportunity to observe Génesis men and women in action with INIFAP advisors.

During the visit our attention seized on a key organizational principle tied to their work-ethic: Génesis insists on a membership comprising only committed, active participants. Subsequent discussions in our small groups highlighted radical differences in agency and voice between the active chorus of Génesis socios (members) and the comparatively muted encounters in a previous visit with other farmers just a few hours away. This issue emerged again when visiting the Veracruz highland community of Micoxtla, above the city of Coatepec, where families struggle with seasonal food insecurity and economic instability. Micoxtla residents expressed the desire to be helped to organize cooperatively in order to enter higher-value local and regional markets. This expression and subsequent interaction eventually led to McRoberts' thesis project (2009) and research collaboration with INIFAP (McRoberts et al., 2013).

These and other field encounters helped bring to life the need to help communities and families to better secure their futures, a priority for the Government of Mexico that was emphasized by the United Nations Special Rapporteur (De Schutter, 2011). Despite gains in reducing the percentage of children under five years of age who are underweight (i.e., Millennium Development Goal \#1), the Special Rapporteur emphasized the unacceptably uneven progress between rural and urban populaces. About $80 \%$ of the 18 million Mexicans living in municipalities characterized by high marginalization are in rural areas. Consequently, the Government of Mexico was urged to improve self-determination in rural communities through greater community participation and capacity building. Recommended actions included implementing mutually reinforcing environmental, agricultural and social protections, among the priorities to improve public policy, education, diets, health care, and family incomes. Calling for a "Third Agrarian Reform" the rapporteur cited a growing income inequality fostered partly by insufficient public support of agriculture. This reform was charged to provide greater public good expenditures, among them greater access to credit and financial services, agricultural technical assistance, and support to producer organizations and cooperatives.

In harmony with De Schutter's recommendations, many students subsequently formulated thesis research projects aimed at helping rural communities diminish their own vulnerability. These projects typically consider multiple goals aligned with the resources and opportunity horizons already dealt to families and communities. In the following sections we summarize outcomes from research endeavors that were initially based on exchanges with families owning livestock. We present results from a set of projects led by five graduate student Experience Latin America alumni-Australian, Japanese, US and two Mexicans-who examined some of the nutrient constraints and farming system dynamics at the root of agrarian vulnerability in Mexico's Gulf region. In every case, coalitions with farmers, farmer organizations, communities, local researchers and students enabled problem definition and project field work. Key institutional partners were INIFAP, Universidad Autónoma de Yucatán (UADY), Unión Ganadera Regional de Yucatán, Unión Ganadera Regional del Oriente de Yucatán, Universidad Veracruzana, and Génesis and Tepetzintla farmer organizations in Veracruz (Note 8). Thus, these collaborations (Note 9) constituted a kind of international consortium of its own making.

\subsection{Cattle Systems}

Animal agriculture is fundamental to the economy of Mexico's Gulf region. Cattle herds, like those owned by Génesis farmers constitute an important livelihood in rural Veracruz, a major supplier of Mexico's beef and milk. However, information for improving the productivity, profitability and sustainability of dual-purpose cattle systems is scarce in tropical Latin America, including Mexico, and likely in tropical agro-ecosystems around the world, especially regarding the benefits and costs of alternative management strategies (Blake \& Nicholson, 2004; Blake, 2008). Assisted by INIFAP Génesis members sought to improve farming performance by substituting traditional forages with more nutritious species to increase milk sales from their herds.

Therefore, working together with INIFAP and Génesis herd owners in what are probably the first published tropical case studies to systematically examine complex energetic interactions (Note 10), Absalon-Medina et al. (2012a, 2012b) evaluated the limitations and potential improvements in milk production and profitability from 
alternative nutritional management. Other students similarly evaluated approaches to overcome productivity bottlenecks in Yucatan beef cattle herds (Baba, 2007) and juvenile female replacements in Tepetzintla herds of the low Huasteca region of Veracruz (Cristóbal-Carballo, 2009). These projects revealed a consistent pattern of key biological (energy) and management constraints on animal performance, which portends broader potential application for improving cattle system performance.

Heretofore unrecognized vulnerabilities were revealed through a study designed to evaluate herd performance limitations parsed by age of cow, physiological status and forage season of the year. The most susceptible management groups were non-lactating cows of all ages and forage seasons, and young cows and herd replacements (heifers) suffering growth retardations. Energy deficits signify repeated opportunity losses across an animal's lifetime, which are manifested in delayed puberty of heifers, fewer offspring born, and less total milk per cow over expected lifetimes. Like past efforts by Génesis farmers, these impediments could be ameliorated by investing in nutritional management and improved forage quality. As a result, diets formulated with better quality grass and legume forages were predicted to increase milk sales by up to $74 \%$ with large economic incentives, about $\$ 600$ to $\$ 1100$ greater predicted net margin per cow. This increase in net margin is large, equaling or exceeding in value the total milk from an additional full lactation per cow lifetime. A similar dietary strategy to assure normal growth also based on low cost, locally-produced feeds, especially available forages (e.g., grass hay, sugarcane, legumes), resulted in heifers that were $20 \%$ younger at first parturition (signifying earlier commencement of milk sales) with lower rearing costs, heavier body weights and greater adipose tissue reserves (Cristóbal-Carballo, 2009).

Large marginal rates of return, the change in net margin per unit increase in variable costs, indicated clear economic incentives to alleviate inherent energy deficits and impaired growth. However, alternative management options may be difficult to implement if they are little practiced, thus generating little knowledge among farmers about potential profitability, and if options are perceived riskier than status quo practices. Ex ante economic assessment of strategies requiring greater nutrient inputs is important because higher production per animal is not always more profitable (Absalon et al., 2012b).

\subsection{Crop-Livestock Systems}

Another set of studies examined the nutrient dynamics underlying smallholder systems and the potential of small ruminants to their sustainability. For more than three millennia the shifting cultivation milpa system in the Yucatán Peninsula has involved the cutting of forest after a fallow period, burning, and planting of maize mixed with squash and beans. Milpa (maize, often multi-cropped with beans) cultivation has been purported to be the only food production method available to farmers in forested areas without draft animals. Slashing and burning clears rocky soils for planting, releases nutrients from slashed vegetation for crop growth, and controls the population of weed seed. A major limitation to the productivity of milpa systems, indeed to food production in the developing world, is soil nutrient depletion. Nutrients and organic matter from animal manure-the world's oldest fertilizer-is a vital input for growing food. Agricultural systems of Yucatán have long comprised multiple species of livestock; and the incorporation of hair sheep, a recent practice, is likely driven by market demand for lamb and mutton in the central region around Mexico City. While all adopters of this practice let manure accumulate by corralling animals, only one third of them fertilize with it. Most of these smallholder producers also cultivate a milpa, but cannot bear the expense of commercial fertilizer. Parsons et al. (2011c) summarized, "Farmers have only recently added sheep to their systems to increase household income, and opportunities may exist to develop greater complementarities between these two farming system components, particularly through manure use." Thus, a prime research objective was to evaluate the effectiveness of sheep manure fertilization rates combined with weed control in sustaining the productivity of milpa cultivation. A study of nutrient fluxes in the milpa system of Yucatán with continual maize cultivation and stover removal to feed animals showed that manuring with four metric tons of dry matter per hectare would sustain the soil stock of phosphorus, but not nitrogen or potassium, indicating threats to sustainability from lost fertility (Parsons et al., 2011c).

A companion study suggested that fertility losses and higher weed pressure were important causes of falling maize yields in milpas. Chemical control required much less labor than hand weeding, and fewer weeds mean greater maize production. Manure fertilization also increased grain and biomass yields. By third and fourth years of cultivation, high maize yields could be achieved only through a combination of manuring and weed control. "Small sheep flocks could theoretically provide a sufficient quantity of manure to fertilize a milpa, potentially allowing fertility to be maintained beyond the normal two years. Technologies that increase yield and maintain plots for a longer period have the potential to change elements of the current milpa system. The success of such practices ultimately depends on livelihood needs and aspirations of the households and the communities in which they live" (Parsons et al., 2009). 
Mixed farming systems are enterprises where animal husbandry and crop cultivation are integrated components of one farming system: livestock are fed crop byproducts or residues (e.g., stubble) and significant income is earned by cropping. These systems provide many benefits to low-resource families and although smallholder households produce a large proportion of the food in the tropics, our understanding of the functioning of their farming systems is limited. To address the gap that he previously identified, Parsons et al. (2011a) developed an integrated crop-livestock model to assess biophysical and economic consequences of farming practices incorporated into sheep systems in Yucatán. The resulting dynamic model comprising stocks, flows and feedbacks integrates scientific and practical knowledge of management, flock dynamics, sheep production, nutrient partitioning, labor and economic components. It also accesses information about sheep performance (productivity and manure quantity) and cropping (weather, crop and soil dynamics) obtained from other simulation models.

Thus this simulation model embodies some of the complex interactions occurring between smallholder farmers, crops and livestock; it is a tool for examining selected suites of integrated crop-livestock practices compared to specialized cropping. Studies using this tool revealed that mixed farming scenarios with sheep provide more family income than specialized enterprises. This outcome capitalized on a lower on-farm price of maize grain, efficient utilization of surplus labor, and exploiting the availability of common land. However, more was not always better. It was most profitable to sell excess grain and maize stover, and instead of stover to use common land to feed livestock, thus warning that more integration may not always improve economic outcomes (Parsons et al., 2011b). This systems-oriented approach drew upon local knowledge, synthesizing it in a manner that added value. Humans often have a limited ability to predict outcomes in dynamically complex systems, such as agriculture, where short-term and long-term behaviors may differ.

\subsection{Collective Action: Value-added Agricultural Products}

Another project embodied a response to rural community interest to organize cooperatively to increase family incomes by accessing higher-value local markets. Communities like Micoxtla in the Veracruz highlands, where most inhabitants work in agriculture, confront multiple livelihood challenges. These include food insecurity, unemployment, and low and variable family incomes, which may be surmounted by the creation of income-generating opportunities. Value-added agricultural products are a potential strategy for earning higher incomes. However, biological and economic uncertainties often must be reduced, especially for this strategy to benefit smallholders. Households may be unable to enter or to compete in high-value agricultural product markets because of low access to market information, seasonal production shortfalls, inconsistent product quality, costly market access and poor infrastructure, all of which increase transaction costs (Holloway et al., 2000). Collective action may help overcome these barriers. Value-added products manufactured and marketed by farmer groups or cooperatives might reduce uncertainty by improving rural livelihoods through collective bargaining, smaller transaction costs, and higher average net incomes.

Most Micoxtla families struggle with seasonal food and economic insecurity. After meeting household needs, the principal sources of cash family income are sales of goat's milk, young goats for meat (cabrito), and eggs. Community members identified growing demand for specialty products for the tourist trade in the nearby city of Xico, including aged cheeses made from goat's milk, as one potential component of a rural development project assisted by INIFAP. The community wanted to explore this option to increase incomes, which would require initial funds beyond the capacity of individual families. Further risks from producing and marketing premium cheeses stem from dynamic biological, economic and social processes like weather patterns, market access, and available land to produce forages. Founding an agrarian cooperative supported with startup technical services and training by INIFAP could help reduce these risks.

Consequently, McRoberts (2009) (McRoberts et al., 2013) worked with the community and INIFAP advisors to assess the ex ante potential of cheese production and marketing through a dairy cooperative comprising 25 families. This assessment was enabled by participatory group action to develop a dynamic mathematical simulation tool. With caveats acknowledged the resulting analysis indicated that a cooperative has substantial potential to improve community incomes while controlling risk under a broad range of environmental and market conditions (McRoberts et al., 2013). Furthermore, this Micoxtla case supports De Schutter's (2011) admonishment to help foster community self-determination using participatory approaches, in this case through both identification and ex ante assessment of potential development interventions. Undertaken with a leading Mexican research and development institution, this case importantly demonstrates a methodological contribution to research and development programming. This approach could be applied more broadly to understand the potential behaviors over time resulting from proposed interventions, to determine their benefits and pitfalls, and to better inform decisions about potential investments by governments, donors, communities and families. 


\section{Intellectual Gains from Cultural Context}

Although these projects cover a limited disciplinary footprint compared to the many needs that were identified, they clearly exemplify learning from cultural agents with efforts to return the favor. Collectively they respond to De Schutter's criteria by providing technical assistance, better understanding of food system function and with methodology and action plans to support local communities' escape from poverty and growth of social capital through collective action. In addition to research publications to inform global audiences, project results were shared with local communities and farmer organizations through our collaborators. On the occasion of an invited presentation (Note 11), Yucatán farmers generously expressed gratitude for the thought-provoking results about cattle system opportunities across the Gulf region. Thus, these agrarian research cases illustrate academe's role in transferring information from the community context to a broader public audience, creating discourse and analysis, and abetting social change along the way.

Our integrative curricular approach, incorporating both formal and communal knowledge producers, has co-evolved in ways that parallel the challenge laid down by Godenzzi (2006),

"to communicate research results, discourse analysis, and critical reflections with the agents of that education so that these may enrich curricula and pedagogical interactions. In this way, these disciplines will be contributing to the formation of intercultural agents capable of reinventing our life in society."

Taking up this challenge, we submit that academe is cultural agency's natural partner. To better fulfill its social educator role academe must provide curricula and pedagogy in ways that echo, connect and create plural discourse among multiple dimensions and disciplines of society. Multiplicative effects may be gotten when students and faculty, key agents themselves and trainers of intercultural agents, learn first-hand by crossing borders. In so doing a more inclusive worldview about life in society is found through another lens, thus providing critical context for needs assessments.

\section{Concluding Remarks}

We have illustrated ways in which academe has employed intercultural agency to embrace a more inclusive worldview that helps to frame and effectively address the challenges of agrarian vulnerability and rural life. By allying with hosts from other walks of life who became key professors, students and faculty become co-learners and collaborators charged with social responsibility in delivering voice, knowledge and understanding to extended audiences. We contend that greater academic agency through more alliances like those demonstrated here, and the necessary education investment to foster them, is needed to achieve equity goals through effective community engagement and applied problem-solving. It also helps ensure that all can participate in public policy decisions, which is part of "reinventing our life in society", Godenzzi's challenge to education. Exposed to an enabling cultural landscape, one carrying messages about the substantive contexts surrounding technical intervention and implementation, students winnow and amplify them through their own engagements, lenses and reflections, finally delivering them through an egalitarian process to academe and society writ large.

\section{Acknowledgements}

We thank Emily Holley and Charles Nicholson for their helpful feedbacks on drafts of this article.

\section{References}

Absalon-Medina, V. A., Blake, R. W., Fox, D. G., Juárez-Lagunes, F. I., Nicholson, C. F., Canudas-Lara, E. G., \& Rueda-Maldonado, B. L. (2012a). Limitations and potentials of dual-purpose cow herds in central coastal Veracruz, Mexico. Tropical Animal Health and Production, 44(6), 1131-1142. http://dx.doi.org/10.1007/s11250-011-0049-1

Absalon-Medina, V. A., Nicholson, C. F., Blake, R. W., Fox, D. G., Juárez-Lagunes, F. I., Canudas-Lara, E. G., \& Rueda-Maldonado, B. L. (2012b). Economic analysis of alternative nutritional management of dual-purpose cow herds in central coastal Veracruz, Mexico. Tropical Animal Health and Production, 44(6), 1143-1150. http://dx.doi.org/ 10.1007/s11250-011-0050-8

Baba, K. (2007). Analysis of productivity, nutritional constraints and management options in beef cattle systems of eastern Yucatan, Mexico: A case study of cow-calf productivity in the herds of Tizimin, Yucatan (Unpublished master's thesis). Cornell University, Ithaca, NY, USA.

Blake, R. W. (2001). Tradition and transition: INTAG 602 and the graduate field of international agriculture and rural development. International Agriculture 602 Millennium Conference on Agricultural Development in the $21^{\text {st }}$ Century (pp. 36-40). International Programs, College of Agriculture and Life Sciences: Cornell University. 
Blake, R. W. (2008). Perspectivas de la investigación pecuaria en el mundo tropical: Utilización de recursos genéticos de ganado bovino. In C. V. Durán \& R. Campos (Eds.), Perspectivas de Conservación, Mejoramiento y Utilización de Recursos Genéticos Criollos y Colombianos en los Nuevos Escenarios del Mejoramiento Animal (pp. 1-17). Valle, Colombia: Universidad Nacional de Colombia.

Blake, R. W., \& Nicholson, C. F. (2004). Livestock, land use change, and environmental outcomes in the developing world. In Owen et al. (Eds.), Responding to the Livestock Revolution-the role of globalization and implications for poverty alleviation (pp. 133-153). United Kingdom: Nottingham University Press.

Cristóbal-Carballo, O. (2009). Management of heifer growth in dual-purpose cattle systems in the low Huasteca region of Veracruz, Mexico (Unpublished master's thesis). Cornell University, Ithaca, NY, USA.

De Schutter, O. (2011). End of Mission to Mexico: Mexico requires a new strategy to overcome the twin challenges of "food poverty" and obesity, says UN food expert. Office of the High Commissioner for Human Rights. Retrieved from http://www.ohchr.org/en/NewsEvents/pages/displaynews.aspx?NewsID=11173

Godenzzi, J. C. (2006). The discourses of diversity: Language, ethnicity and interculturality in Latin America. In D. Sommer (Ed.), Cultural Agency in the Americas (pp. 146-166). Durham, NC: Duke University Press.

Holloway, G., Nicholson, C. F., Delgado, C., Stall, S., \& Ehui, S. (2000). Agroindustrialization through institutional innovation, transaction costs, cooperatives and milk-market development in the east-African highlands. Agricultural Economics, 23, 279-288. http://dx.doi.org/10.1111/j.1574-0862.2000.tb00279.x

McRoberts, K. (2009). Rural development challenges: System dynamics ex ante decision support for agricultural initiatives in southern Mexico (Unpublished master's thesis). Cornell University, Ithaca, NY, USA.

McRoberts, K. C., Nicholson, C. F., Blake, R. W., Tucker, T. W., \& Díaz-Padilla, G. (2013). Group model building to assess rural dairy cooperative feasibility in south-central Mexico. International Food and Agribusiness Management Review, 16(3), 55-98.

Meredith, R. A. (2010). Acquiring cultural perceptions during study abroad: The influence of youthful associates. Hispania, 93(4), 686-702.

Parsons, D., Ketterings, Q. M., Cherney, J. H., Blake, R. W., Ramírez-Aviles, L., \& Nicholson, C. F. (2011c). Effects of weed control and manure application on nutrient fluxes in the shifting cultivation milpa system of Yucatán. Archives of Agronomy and Soil Science, 57(3), 273-292. http://dx.doi.org/10.1080/03650340903307236

Parsons, D., Nicholson, C. F., Blake, R. W., Ketterings, Q. M., Ramírez-Aviles, L., Fox, D. G., .. Cherney, J. H. (2011a). Development and evaluation of an integrated simulation model for assessing smallholder crop-livestock production in Yucatán, Mexico. Agricultural Systems, 104, 1-12. http://dx.doi.org/10.1016/j.agsy.2010.07.006

Parsons, D., Nicholson, C. F., Blake, R. W., Ketterings, Q. M., Ramírez-Aviles, L., Cherney, J. H., \& Fox, D. G. (2011b). Application of a simulation model for assessing integration of smallholder shifting cultivation and sheep production in Yucatán, Mexico. Agricultural Systems, 104, 13-19. http://dx.doi.org/10.1016/j.agsy.2010.07.006

Parsons, D., Ramírez-Aviles, L., Cherney, J. H., Ketterings, Q. M., Blake, R. W., \& Nicholson, C. F. (2009). Managing maize production in shifting cultivation milpa systems in Yucatán through weed control and manure application. Agriculture Ecosystems and Environment, 133(1-2), 123-134. http://dx.doi.org/10.1016/j.agee.2009.05.011

Sommer, D. (2006). Introduction: Wiggle room. In D. Sommer (Ed.), Cultural Agency in the Americas (pp. 1-28). Durham: Duke University Press.

Thurston, H. D. (2001). A living laboratory: Field study in agriculture and agricultural development. International Agriculture 602 Millennium Conference on Agricultural Development in the $21^{\text {st }}$ Century (pp. 33-35). International Programs, College of Agriculture and Life Sciences, Cornell University.

\section{Notes}

Note 1. This cross-college course was entitled Bridging Worlds: Rural and Urban Realities. Retrieved from http://ip.cals.cornell.edu/courses/iard4010/ 
Note 2. Experience Latin America. Retrieved from http://ip.cals.cornell.edu/courses/iard6010/

Note 3. Practitioners of cultural agency, as defined by Sommer (2006), exploit "a vehicle for agency through creative actions and reflections that influence collective change". Other variants affecting collective action and change may include political agency and community agency.

Note 4. Chiapas field coordinators were Dr. Carlos Riqué Flores and Blanca Concepción (Conchita) Guzmán de Riqué. Host institutions in 2005-08 were the Universidad Autónoma de Yucatán, Universidad Veracruzana and INIFAP, also with student and faculty participation partially supported through a Training, Internships, Exchanges and Scholarships project funded by USAID-Mexico through Higher Education for Development (http://tiesmexico.cals.cornell.edu/).

Note 5. Vice Provost, University Outreach and International Programs, University of California, Davis. Dr. Lacy was the Director of Cornell Cooperative Extension and Associate Dean of the Colleges of Agriculture and Life Sciences, and Human Ecology at Cornell University, 1994-1998.

Note 6. Personal communication appearing in Blake (2001).

Note 7. Professor Dow's advice was part of the 1999 exhibition of Georgia O'Keefe's work at the Phillips Museum in Washington, D.C. Thereafter it was added to our course strategy materials.

Note 8. These organizations are widely known as a Grupo Ganadero de Validación y Transferencia de Tecnología (GGAVATT), or GGAVATT Génesis and GGAVATT Tepetzintla.

Note 9. Decision Support of Ruminant Livestock Systems. Retrieved from http://tiesmexico.cals.cornell.edu

Note 10. These interactions involve dietary energy balance, milk production and expected growth, and indirectly, their potential effects on herd reproduction.

Note 11. "Limitaciones y Manejo Alternativo para la Producción de Carne en los Trópicos" (Limitations and Alternative Management for Beef Production in the Tropics), invited presentation by R. W. Blake (2010) at Día del Ganadero 2010 (Cattleman's Field Day 2010), INIFAP Sitio Experimental Tizimín, Tizimín, Yucatán, México.

\section{Copyrights}

Copyright for this article is retained by the author(s), with first publication rights granted to the journal.

This is an open-access article distributed under the terms and conditions of the Creative Commons Attribution license (http://creativecommons.org/licenses/by/3.0/). 